\title{
PERANCANGAN DATA WAREHOUSE RUMAH SAKIT BERBASIS ONLINE ANALYTICAL PROCESSING (OLAP)
}

\author{
Joko Purwanto $^{* 1}$, Renny ${ }^{2}$ \\ 1,2 Universitas Gunadarma Depok \\ jpur1to@yahoo.co.id ${ }^{1}$, renirana@ staff.gunadarma.ac.id ${ }^{2}$ \\ *Penulis Korespondensi
}

(Naskah masuk: 12 Oktober 2020, diterima untuk diterbitkan: 19 Oktober 2021)

\begin{abstract}
Abstrak
Pemanfaatan teknologi informasi sangat penting bagi rumah sakit, karena berpengaruh pula terhadap kualitas pelayanan kesehatan yang secara manual diubah menjadi digital dengan menggunakan teknologi informasi.

Dalam penelitian ini penulis menggunakan metodologi Nine step sebagai acuan dalam merancang suatu data warehouse, untuk pemodelan menggunakan skema konstelasi fakta dengan 3 tabel fakta dan 11 tabel dimensi. Perbedaan penelitian ini dengan penelitian sebelumnya terletak pada sumber data yang diekstrak langsung dari database SIMRS yang digunakan rumah sakit, sehingga tidak ada ekstraksi data secara manual.

Penelitian ini bertujuan untuk menghasilkan desain data warehouse berbasis Online Analytical Processing (OLAP) sebagai sarana penunjang kualitas pelayanan kesehatan rumah sakit. OLAP yang dihasilkan akan berupa desain data warehouse dengan berbagai dimensi yang akan menghasilkan tampilan informasi berupa Chart maupun Grafik sehingga informasinya mudah dibaca dan dipahami oleh berbagai pihak.
\end{abstract}

Kata kunci: data warehouse, nine step methodologi, ETL, OLAP, SIMRS

\section{HOSPITAL DESIGN OF DATA WAREHOUSE BASED ON ONLINE ANALYTICAL PROCESSING (OLAP)}

\begin{abstract}
The use of information technology is very important for hospitals, because it also affects the quality of health services, which manualy changed to digital using information technology. In this study, the authors used the Nine step methodology as a reference in designing a data warehouse for modeling using a fact constellation schema with 3 fact tables and 11 dimension tables. the different in this study from previous research is that the data source was taken directly from the SIMRS database used by the hospital, so there is no manual data extraction.

The aim of this research is to be able to produce a Data Warehouse design based on Online Analytical Processing (OLAP) as a means of supporting the quality of hospital health services. The resulting OLAP will be a data warehouse design with various dimensions will produce the displays information in the form of a graph or chart so that the information is easy to read and understand by various parties.
\end{abstract}

Keywords: data warehouse, nine step methodologi, ETL, OLAP, HIS

\section{PENDAHULUAN}

Fenomena era revolusi industri 4.0 dan society 5.0 mendorong terciptanya inovasi dalam teknologi, dimana era ini memberikan dampak disrupsi yang membawa banyak perubahan besar dalam berbagai bidang industri serta memiliki dampak terhadap pola kehidupan masyarakat. Perkembangan teknologi sangatlah pesat, terlebih teknologi memiliki peranan penting. Hal ini memberi tantangan tersendiri bagi dunia industri tak terkecuali industri rumah sakit. Pengaruh kemajuan teknologi sudah merambah masuk ke bidang kesehatan, dimana aspek kesehatan memiliki nilai penting bagi manusia.

Pemanfaatan teknologi informasi sangatlah penting bagi rumah sakit, karena turut mempengaruhi mutu pelayanan kesehatan yang awalnya manual berubah menjadi digitals dengan memanfaatkan teknologi informasi. Layanan digitalisasi dalam kesehatan menjadi keniscayaan yang mendorong rumah sakit untuk dapat menghadirkan pelayanannya lebih efektif dan efisien.

baik pula. Sehingga rumah sakit yang telah memanfaatkan sistem informasi manajemen rumah sakit atau sering disebut SIMRS menjadi salah satu indikator 
kualitas pelayanan kesehatan. Karena bukan tanpa alasan penerapan SIMRS menjadi salah satu acuan barometer penilaian manajemen rumah sakit yang baik. Kesuksesan dalam mengimplementasikan SIMRS, rumah sakit dapat memberikan layanan kesehatan yang lebih cepat dan tepat dalam pelayanannya. Sehinnga pelayanan rumah sakit terhadap para pasiennya akan menjadi lebih efektif dan efisien, dengan salah satunya dalam proses pencarian data dan riwayat kesehatan pasien dapat dengan mudah di akses dalam database SIMRS, sehingga akan membantu dalam menentukan tindakan medis yang sesuai secara lebih cepat dan tepat.

Seiring perkembangan rumah sakit, maka akan semakin banyak dan komplek data yang dimilikinya. Dengan jumlah data pasien yang banyak dan terus bertambah sering menyulitkan para eksekutif dalam melakukan analisis terhadap data pasien guna membantu dalam pengambilan keputusan manajemen dengan cepat dan tepat. Hal ini berdampak pada waktu pembuatan laporan yang dibutuhkan dinilai relatif masih lama. Selain itu laporan yang tersedia pada sistem saat ini, pihak eksekutif menilai informasi yang disajikan masih sangat terbatas. Sehingga berdampak pada pengambilan keputusan yang diambil dinilai masih kurang maksimal.

Untuk itu diperlukannya perancangan teknologi informasi yang mampu menangani dan mengolah basis data dalam jumlah besar guna memanfaatkan semaksimal mungkin seluruh informasi yang tersedia. Dengan karakterstik masalah tersebut, hal yang dapat dilakukan guna mengatasi permasalahan adalah dengan melakukan perancangan dan membangun data warehouse, dimana seluruh basis data akan di integrasikan dan di gali seluruh informasinya guna menghasilkan intisari informasi yang penting dari data untuk mendukung dalam pengambilan keputusan.

Kimbal \& Ross (2001) mengatakan terdapat 9 langkah dalam membangun sebuah data warehouse, yang dikenal dengan nine step methodology. Pada penelitian ini penulis menggunakan Nine step methodology sebagai acuan dalam merancang data warehouse pada Rumah Sakit Swasta yang terletak di salah satu kawasan industri modern. Untuk pemodelannya pada penelitian ini menggunakan fact constelation schema dengan 3 tabel fakta yaitu tabel fakta registrasi kunjungan, tabel fakta pasien dan tabel fakta episode diagnosa. Pemodelan tersebut dipilih berdasarkan studi kasus pada pelaporan registrasi kunjungan pasien dan pelaporan diagnosa pasien.

Sedangkan untuk dimensi pada penelitian ini memiliki 11 dimensi, yaitu dimensi jenis kunjungan, dimensi kategori pasien, dimensi service unit, dimensi jenis kelamin, dimensi dokter, dimensi diagnosa, dimensi tipe penjaminan, dimensi penjamin, dimensi pekerjaan, dimensi Agama dan dimensi status pasien. Pemilihan dimensi pada penelitian ini ditentukan berdasarkan kebutuhan dalam pelaporan yang dibutuhkan Rumah Sakit.

Ada 3 keunikan yang membedakan pada penelitian ini dengan penelitian sebelumnya, dimana sumber data pada penelitian ini diambil langsung dari database SIMRS yang digunakan rumah sakit, sehingga data ekplorasi laporan yang akan dihasilkan akan lebih akurat karena diekstrak langsung dari sumber data, tidak ada ekstrak data manual seperti pada penelitian sebelumnya. Disisi tampilan, pelaporan pada penelitian ini menggunakan aplikasi Tableau Desktop versi 2018.3. Eksplorasi laporan yang dihasilkan lebih menarik dalam penyajiannya, dengan feature yang dimiliki Tableau Desktop mampu menyajikan variasi penyajian laporan yang manarik namun tetap informatif. Berbeda dengan sebelumnya yang menggunakan pivot tabel Microsoft Excel. Pada sisi sumber data pada penelitian ini menggunakan 3 tabel fakta dengan 11 dimensi sehingga mampu menyajikan laporan yang lengkap untuk para pengguna dan pengambil keputusan.

\section{METODE PENELITIAN}

\section{1 . Online Analytical Processing (OLAP)}

Menurut Wiliam C. Amo (2000) Online Analytical Processing (OLAP) merupakan salah satu tools yang digunakan untuk mengakses informasi dalam data warehouse secara efektif untuk proses online analysis, memberikan respon yang cepat terhadap analytical queries yang kompleks (Wiliam, C.Amo, 2000). Multidimensional data model dapat diartikan sebuah cara pandang melihat data berdasarkan cara pandang multidimensi agar dapat mengoptimalkan analisis data berdasarkan dari relational database dan kemudian diolah menjadi informasi yang dapat dikategorikan berdasarkan dimensi, sehingga pengguna bisa melihat dari beberapa macam cara/sudut pandang. OLAP memiliki teknik agregasi data yang difungsikan untuk mengatur dan mengelola data untuk dapat menghasilkan kesimpulan dengan data dalam jumlah cukup besar, sehingga diharapkan pengguna dapat dengan mudah dan cepat dalam menganalisa menggunakan online analysis dan graphical tool. Selain itu sistem OLAP dapat memberikan fleksibilitas dalam melakukan analisis terhadap data secara real time.

\subsection{Data warehouse}

Data yang dikoleksi pada data warehouse mempunyai sifat yang berorientasikan pada subjek, yang telah terintegrasi dan memiliki atribut time variant serta bersifat tetap sehingga data yang dihasilkan dapat mendukung proses pengembalian keputusan management. Secara fisik, data warehouse adalah database, tetapi dalam perancangan data warehouse dan database sangatlah berbeda. Dalam perancangan database tradisional menggunakan normalisasi, sedangkan pada data warehouse, normalisasi bukanlah cara yang terbaik. (W.H. Inmom dan Richard D.H., 2005).

Tujuan dari data warehouse salah satunya untuk mengintegrasikan data source yang dimiliki perusahaan ke dalam sebuah repository data, yang nantinya akan digunakan dalam menjalankan suatu query data guna menghasilkan suatu laporan yang memudahkan pengguna dalam menganalisa, untuk mengambil 
keputusan dengan lebih mudah, cepat dan akurat. Pada gambar 1 dibawah ini digambarkan bagaimana arsitektur data warehouse menurut Ponniah.

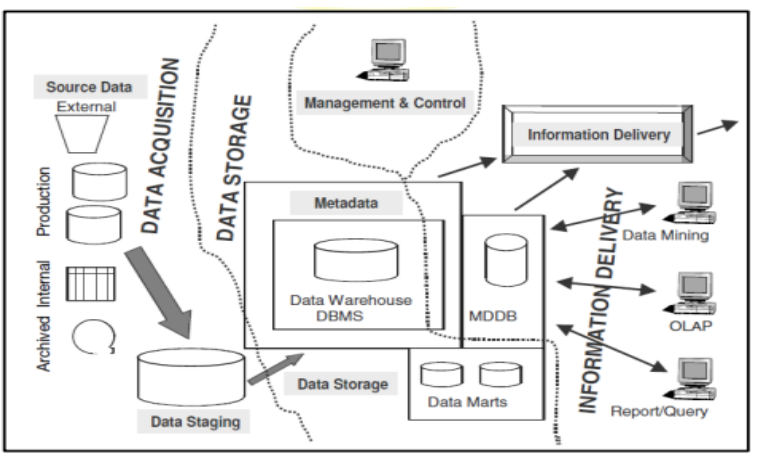

Gambar 1 Arsitektur data warehouse

(Ponniah, 2001)

\subsection{Dimensional Modelling}

Dimensionality modelling adalah sebuah teknik desain logis yang bertujuan untuk menghadirkan data dalam sebuah bentuk yang standar dan intuitif yang memungkinkan pengaksesan basis data dengan performa yang tinggi (Connolly dan Begg, 2001:1183).

Dalam data warehouse ada tiga konsep permodelan pada dimensionality modelling, konsep-konsep tersebut dikenal pada umunya diantaranya; star schema, snowflake dan fact constellation schema.

\subsection{ETL (Extract, Transform, Load)}

Proses ETL merupakan proses yang pertama kali dilakukan dalam membangun data warehouse, dimana dalam proses ini dilakukannya migrasi data dari database operasional menjadi data warehouse. Proses ETL akan dilakukan secara berkala guna meng-update data warehouse. Proses ETL terdiri dari empat fase yang terpisah : extraction (atau capture), cleansing (atau cleaning atau scrubbing), transformation, dan loading (Golfarelli dan Rizzi, 2009:15).

\subsection{Metode Perancangan Data Warehouse}

Metode perancangan data warehouse menurut Kimball meliputi 9 tahap yang dikenal dengan Ninestep methodology (Connolly dan Begg, 2005:1187). Kesembilan tahap tersebut yaitu :

1. Pemilihan Proses (Choosing the process)

2. Pemilihan Grain (Choosing the grain)

3. Identifikasi dari penyampaian dimensi (Indentifying and conforfming the dimensions).

4. Pemilihan fakta (Choosing the facts)

5. Penyimpanan pre-calculation di tabel fakta (Storing pre-calculation in the fact table)

6. Memastikan tabel dimensi (Rounding out the dimensions tables)

7. Pemilihan durasi database (Choosing the duration of the database)

8. Melacak perubahan dari dimensi secara perlahan (Tracking slowly changing dimensions)

9. Penentuan prioritas dan model query (Deciding the query priorities and the query modes)

\section{Metode Penelitian}

Penelitian ini dilakukan melalui tahap analisis, desain, proses ETL, penerapan OLAP, eksplorasi hasil laporan dan analisis seperti yang ditunjukkan dalam kerangka penelitian pada Gambar 2 dibawah ini:

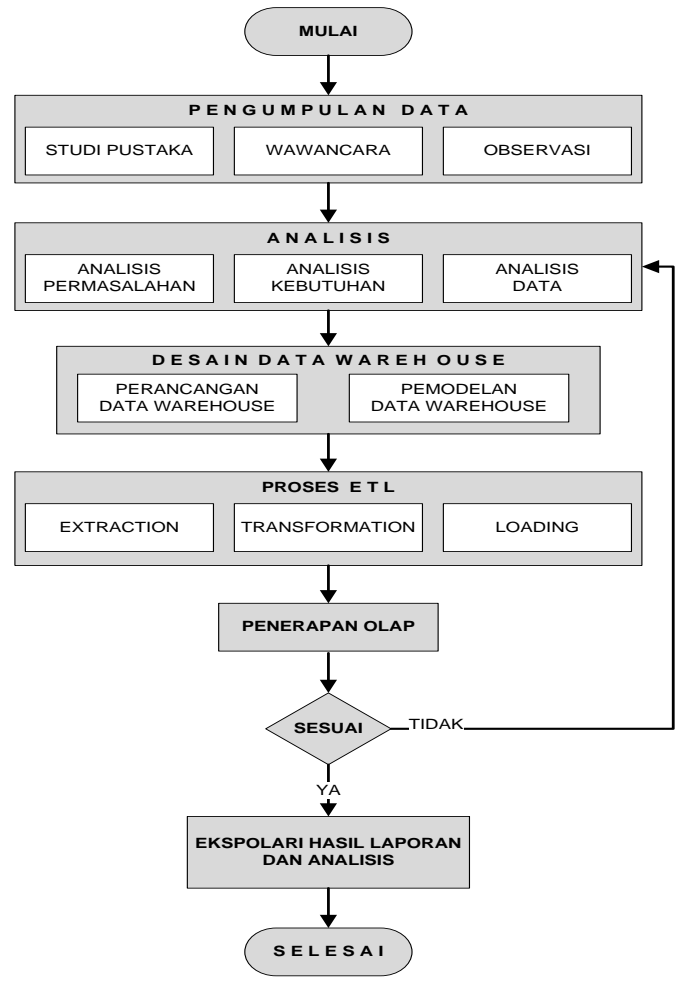

Gambar 2. Kerangka pemikiran

\section{HASIL DAN PEMBAHASAN}

\subsection{Analisis}

Berdasarkan dari hasil analisa dapat diketahui bahwa kebutuhan yang diinginkan para manajer rumah sakit, diperlukannya sebuah sistem yang dapat membantu dalam pekerjaan para manajer dalam mengolah data menjadi sebuah laporan yang akan dipresentasikan dalam meeting, dengan berbagai format yang mudah untuk disesuaikan berdasarkan kebutuhan serta tanpa perlu lagi melakukan perhitungan secara manual. Dimana laporan yang dibutuhkan haruslah memiliki format yang beragam sesuai dengan kebutuhan, yang didalamnya dapat memuat analisis multidimensional dan dalam bentuk grafik dan chart analisis yang memudahkan dalam pengambilan sebuah keputusan.

Data yang tersedia pada data warehouse didapat dari hasil penyeleksian data source yang diambil dari database SIMRS, setelah dilakukan pembersihan data yang dibutuhkan dan disesuaikan dengan kebutuhan penelitian, sehingga tidak semua data dapat disajikan. Berikut ini adalah beberapa atribut data yang diambil dari database SIMRS:

Tabel 4.1 Atribut data pasien pada SIMRS

\begin{tabular}{ccc}
\hline No. & Atribut & Keterangan \\
\hline 1 & PatientID & Nomer Pasien
\end{tabular}




\begin{tabular}{ccc}
\hline No. & Atribut & Keterangan \\
\hline 2 & MedicalNo & Nomer Rekam Medis \\
3 & DateOfBirth & Tanggal Lahir \\
4 & GenderID & Jenis Kelamin \\
5 & OccupationID & Pekerjaan \\
6 & PatientCategoryID & Kategori Pasien \\
\hline 7 & ReligionID & Agama \\
8 & GuarantorID & Penjamin \\
9 & County & Daerah \\
\hline Tabel 4.2 & Atribut data registrasi pada SIMRS \\
\hline No. & Atribut & Keterangan \\
\hline 1 & RegistrationNo & Nomer Registrasi \\
2 & RegistrationTypeID & Tipe Registrasi \\
3 & ParamedicID & Kode Paramedic \\
4 & GuarantorID & Kode Asuransi \\
5 & PatientID & Kode Pasien \\
6 & RegistrationDate & Tanggal Registrasi \\
7 & PatientCategoryID & Kategori Pasien \\
8 & ServiceUnitID & Kode Service Unit \\
9 & IsNewPatient & Pasien Baru \\
\hline
\end{tabular}

Tabel 4.3 Atribut data epidose diagnosa pada SIMRS

\begin{tabular}{|c|c|c|}
\hline No. & Atribut & Keterangan \\
\hline 1 & RegistrationNo & Nomer Registrasi \\
\hline 2 & DiagnoseID & Kode Diagnosa \\
\hline 4 & DiagnosisText & Nama Diagnosa \\
\hline 5 & ParamedicID & Kode Paramedic \\
\hline \multicolumn{3}{|c|}{ Tabel 4.4 Atribut data diagnosa pada SIMRS } \\
\hline No. & Atribut & Keterangan \\
\hline 1 & DiagnoseID & Kode Diagnosa \\
\hline 2 & DiagnoseName & Nama Diagnosa \\
\hline
\end{tabular}

Tidak semua atribut data yang tersimpan pada tabel database Sistem Informasi Manajemen Rumah Sakit (SIMRS) digunakan dalam data warehouse yang akan dibangun pada penelitian ini. Terdapat beberapa atribut yang tidak boleh digunakan dengan alasan untuk menjaga kerahasiaan data baik secara regulasi database rumah sakit maupun regulasi data rekam medis pasien. Atribut yang digunakan dipilih dan disesuaikan dengan kebutuhan penelitian dan atribut yang tidak digunakan maupun yang tidak boleh digunakan akan dihapus pada data warehouse yang akan dibangun pada penelitian ini.

Tabel 4.5 Penjelasan tabel dimensi

\begin{tabular}{|c|c|c|}
\hline Dimensi & Atribut & Keterangan \\
\hline Diagnosa & $\begin{array}{c}\text { Kode Diagnosa } \\
\text { Diagnosa }\end{array}$ & $\begin{array}{l}\text { Laporan dapat dibuat } \\
\text { berdasarkan Diagnosa }\end{array}$ \\
\hline $\begin{array}{c}\text { Jenis } \\
\text { Kelamin }\end{array}$ & Kode Jenis Kelamin & $\begin{array}{c}\text { Laporan dapat dibuat } \\
\text { berdasarkan Jenis } \\
\text { Kelamin }\end{array}$ \\
\hline $\begin{array}{l}\text { Kelompok } \\
\text { Pekerjaan }\end{array}$ & $\begin{array}{c}\text { Kode Kelompok } \\
\text { Pekerjaan } \\
\text { Kelompok Pekerjaan }\end{array}$ & $\begin{array}{c}\text { Laporan dapat dibuat } \\
\text { berdasarkan Kelompok } \\
\text { Usia }\end{array}$ \\
\hline $\begin{array}{l}\text { Kategori } \\
\text { Pasien }\end{array}$ & $\begin{array}{l}\text { Kode Kategori } \\
\text { Pasien } \\
\text { Nama Kategori } \\
\text { Pasien }\end{array}$ & $\begin{array}{c}\text { Laporan dapat dibuat } \\
\text { berdasarkan Kategori } \\
\text { Pasien }\end{array}$ \\
\hline $\begin{array}{c}\text { Jenis } \\
\text { Kunjungan }\end{array}$ & $\begin{array}{c}\text { Kode Jenis } \\
\text { Kunjungan } \\
\text { Jenis Kunjungan }\end{array}$ & $\begin{array}{c}\text { Laporan dapat dibuat } \\
\text { berdasarkan Jenis } \\
\text { Kunjungan }\end{array}$ \\
\hline
\end{tabular}

\begin{tabular}{|c|c|c|}
\hline Dimensi & Atribut & Keterangan \\
\hline Penjamin & $\begin{array}{l}\text { Kode Penjamin } \\
\text { Penjamin }\end{array}$ & $\begin{array}{l}\text { Laporan dapat dibuat } \\
\text { berdasarkan Penjamin }\end{array}$ \\
\hline $\begin{array}{c}\text { Tipe } \\
\text { Penjamin }\end{array}$ & Kode Tipe Penjamin & $\begin{array}{l}\text { Laporan dapat dibuat } \\
\text { berdasarkan Jenis }\end{array}$ \\
\hline \multirow{2}{*}{ Service Unit } & $\begin{array}{c}\text { Nama Tipe Penjamin } \\
\text { Kode Service Unit }\end{array}$ & \multirow{2}{*}{$\begin{array}{c}\text { Laporan dapat dibuat } \\
\text { bedasarkan Service Unit }\end{array}$} \\
\hline & Nama Service Unit & \\
\hline Dokter & $\begin{array}{l}\text { Kode Dokter } \\
\text { Nama Dokter }\end{array}$ & $\begin{array}{l}\text { Laporan dapat dibuat } \\
\text { bedasarkan Dokter }\end{array}$ \\
\hline Agama & $\begin{array}{c}\text { Kode Regilion } \\
\text { Agama Kepercayaan }\end{array}$ & $\begin{array}{l}\text { Laporan dapat dibuat } \\
\text { berdasarkan Agama } \\
\text { Pasien }\end{array}$ \\
\hline \multirow{2}{*}{ Status Pasien } & Kode Status Pasien & \multirow{2}{*}{$\begin{array}{c}\text { Laporan dapat dibuat } \\
\text { berdasarkan Status } \\
\text { Pasien }\end{array}$} \\
\hline & Initial Status Pasien & \\
\hline
\end{tabular}

\subsection{Perancangan Data Warehouse}

Perancangan data warehouse menggunakan nine step methodology yang disesuaikan dengan kebutuhan rumah sakit. Dalam proses perancangan terdiri dari:

1. Pemilihan Proses; Berdasarkan dari hasil pengamatan dipilihlah registrasi kunjungan pasien sebagai proses dalam perancangan data warehouse

2. Pemilihan Grain; Guna menentukan secara pasti data apa yang mewakilkan sebagai tabel fakta berdasarkan kebutuhan laporan dipilihlah informasi registrasi, data pasien dan data diagnosa terbanyak yang diderita pasien.

3. Identifikasi dan penyampaian dimensi; Pada langkah ini berdasarkan grain yang telah dipilih terdapat 11 dimensi sebagai sudut pandang yang menggambarkan fakta pada tabel fakta yang dipilih pada data warehouse.

4. Memilih fakta; Pada tahapan ini ditetapkan tabel fakta yang mampu menginterprestasikan grain adalah tabel fakta registrasi, fakta pasien dan fakta episode diagnosa.

5. Menyimpan pre-calculation; Tahapan selanjutnya adalah dilakukan proses kalkulasi terhadap 3 tabel fakta pada atribut terpilih dimana hasil dari perhitungan akan disimpan pada database dalam data warehouse.

6. Melengkapi tabel dimensi; Pada tahapan ini dimensi yang telah teridentifikasi diberikan uraian keterangan secara lengkap guna memudahkan pengguna data warehouse dalam memahaminya sudut pandangan data.

7. Pemilihan durasi; Proses ini dilakukan guna menentukan durasi waktu pada basis data. Dalam pembuatan data warehouse ini ditetapkan durasi waktu 2 tahun terhitung Rumah Sakit mulai beroperasional.

8. Melacak perubahan dari dimensi; Dalam proses ini atribut dimensi yang mungkin berubah adalah dimensi 
service unit dan tipe penjamin. Dimana dimungkinkan terjadinya perubahan status data aktif atau non aktif.

9. Penentuan prioritas dan model query; Pada tahapan terakhir ini akan dibuatnya query data dan pemodelan perancangan data warehouse dengan menggunakan fact constellation schema dari 3 tabel fakta dan 11 dimensi.

Berikut skema fact constellation pada Gambar 3 dibawah ini:

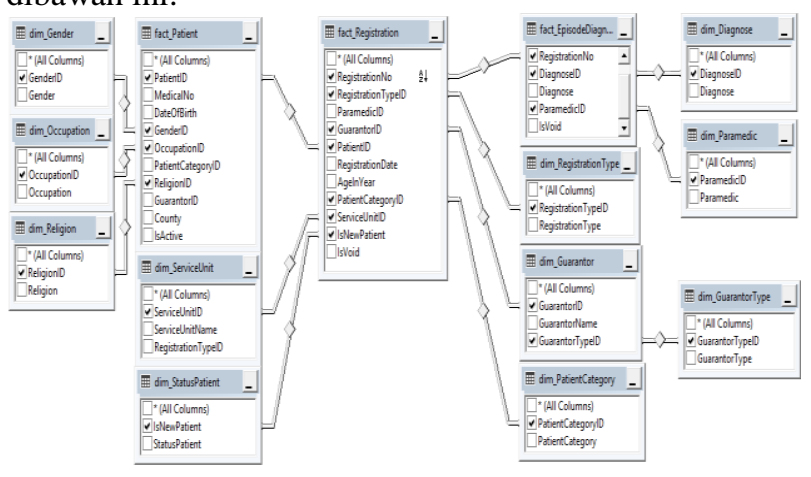

Gambar 3. Fact constellation schema

Berdasarkan hasil perancangan data warehouse terdapat tiga fakta tabel yaitu fakta registrasi kunjungan, fakta pasien dan fakta episode diagnosa. Terbentuknya tiga tabel fakta ditentukan berdasarkan studi kasus dimana perhitungan jumlah registrasi dihitung berdasarkan transaksi registrasi pasien, sedangkan untuk perhitungan jumlah pasein dilakukan berdasarkan pasien yang terdaftar, dan untuk diagnosa dilakukan berdasarkan record diagnose yang di derita oleh pasien, sehingga dipilih tiga fakta tersebut.

Tabel 4.8 Daftar tabel dimensi dan tabel fakta

\begin{tabular}{cll}
\hline No & \multicolumn{1}{c}{ Daftar Tabel } & \multicolumn{1}{c}{ Nama Tabel } \\
\hline 1 & Fakta Registrasi & fact_Registration \\
2 & Fakta Pasien & fact_Patient \\
3 & Fakta Episode Diagnosa & fact_EpisodeDiagnose \\
4 & Dimensi Diagnosa & dim_Diagnose \\
5 & Dimensi Dokter & dim_Paramedic \\
6 & Dimensi Pekerjaan Pasien & dim_Occupation \\
7 & Dimensi Penjamin & dim_Guarantor \\
8 & Dimensi Tipe Penjamin & dim_GuarantorType \\
9 & Dimensi Jenis Kunjungan & dim_RegistrationType \\
10 & Dimensi Kategori Pasien & dim_PatientCategory \\
11 & Dimensi Service Unit & dim_ServiceUnit \\
12 & Dimensi Jenis Kelamin & Dim_Gender \\
13 & Dimensi Agama & dim_Religion \\
14 & Dimensi Pasien Baru & dim_StatusPasien \\
\hline
\end{tabular}

Metadata pada masing-masing tabel fakta dan tabel dimensi dijelaskan sebagai berikut :

Tabel 4.9 Metadata tabel fakta kunjungan (fact_Registration)

\begin{tabular}{ccc}
\hline Atribut & Tipe Data & Panjang \\
\hline RegistrationNo & varchar & 20 \\
RegistrationType & varchar & 20 \\
ParamedicID & varchar & 10
\end{tabular}

\begin{tabular}{ccc} 
GuarantorID & varchar & 10 \\
PatientID & varchar & 15 \\
RegistrationDate & datetime & - \\
PatientCategory & varchar & 20 \\
ServiceUnitID & varchar & 10 \\
IsNewPatient & bit & - \\
\hline
\end{tabular}

Tabel 4.10 Metadata tabel fakta pasien (fact_Patient)

\begin{tabular}{ccc}
\hline Atribut & Tipe Data & Panjang \\
\hline PatientID & varchar & 15 \\
MedicalNo & varchar & 15 \\
DateOfBirth & datetime & \\
GenderID & char & 1 \\
OccupationID & varchar & 20 \\
PatientCategoryID & varchar & 20 \\
ReligionID & varchar & 20 \\
County & varchar & 50 \\
GuarantorID & varchar & 10 \\
\hline
\end{tabular}

Tabel 4.11 Metadata tabel fakta episode diagnosa (fact_EpisodeDiagnosa)

\begin{tabular}{ccc}
\hline Atribut & Tipe Data & Panjang \\
\hline RegistrationDate & datetime & 20 \\
DiagnoseID & varchar & 20 \\
DiagnosisText & varchar & 256 \\
ParamedicID & varchar & 10 \\
\hline
\end{tabular}

Tabel 4.12 Metadata tabel dimensi jenis kelamin (dim_Sex)

\begin{tabular}{ccc}
\hline Atribut & Tipe Data & Panjang \\
\hline GenderID & varchar & 1 \\
Gender & varchar & 10 \\
\hline
\end{tabular}

Tabel 4.14 Metadata tabel dimensi pekerjaan (dim_Occupation)

\begin{tabular}{ccc}
\hline Atribut & Tipe Data & Panjang \\
\hline OccupationID & varchar & 10 \\
Occupation & varchar & 50 \\
\hline
\end{tabular}

Tabel 4.15 Metadata tabel dimensi daerah (dim_Religion)

\begin{tabular}{ccc} 
Atribut & Tipe Data & Panjang \\
\hline ReligionID & varchar & 10 \\
Religion & varchar & 100 \\
\hline
\end{tabular}

Tabel 4.16 Metadata tabel dimensi jenis kunjungan (dim_RegistrationType)

\begin{tabular}{ccc}
\hline Atribut & Tipe Data & Panjang \\
\hline RegistrationTypeID & varchar & 3 \\
\hline RegistrationType & varchar & 20 \\
\hline
\end{tabular}

Tabel 4.17 Metadata tabel dimensi penjamin (dim_Guarantor)

\begin{tabular}{ccc}
\hline Atribut & Tipe Data & Panjang \\
\hline GuarantorID & varchar & 10 \\
GuarantorName & varchar & 100 \\
GuatantorTypeID & varchar & 20 \\
\hline
\end{tabular}

Tabel 4.17 Metadata tabel dimensi penjamin (dim_Guarantor) 


\begin{tabular}{ccc}
\hline Atribut & Tipe Data & Panjang \\
\hline GuarantorTypeID & varchar & 20 \\
GuarantorType & varchar & 50 \\
\hline
\end{tabular}

Tabel 4.18 Metadata tabel service unit (dim_ServiceUnit)

\begin{tabular}{|c|c|c|}
\hline Atribut & Tipe Data & Panjang \\
\hline ServiceUnitID & varchar & 10 \\
\hline Service Unit Name & varchar & 100 \\
\hline
\end{tabular}

Tabel 4.19 Metadata tabel dimensi dokter (dim_Paramedic)

\begin{tabular}{ccc}
\hline Atribut & Tipe Data & Panjang \\
\hline ParamedicID & varchar & 10 \\
Paramedic & varchar & 255 \\
\hline
\end{tabular}

Tabel 4.20 Metadata tabel dimensi diagnosa (dim_Diagnose)

\begin{tabular}{ccc}
\hline Atribut & Tipe Data & Panjang \\
\hline DiagnoseID & varchar & 20 \\
Diagnose & varchar & 4000 \\
\hline
\end{tabular}

Tabel 4.21 Metadata tabel dimensi status (dim_StatusPasien)

\begin{tabular}{ccc}
\hline Atribut & Tipe Data & Panjang \\
\hline StatusID & varchar & 1 \\
Initial StatusID & varchar & 1 \\
\hline
\end{tabular}

\subsection{Proses Extraction, Transformation, Loading} (ETL)

Proses ETL (extract, transform, load) adalah proses yang digunakan dalam memproses data sebelum dimasukkan ke dalam suatu data warehouse. Proses ini dilakukan untuk mestandarisasikan data yang akan digunakan pada data warehouse. ETL adalah langkah penting dalam pembuatan data warehouse. Proses ETL dilakukan secara periodic dan otomatis
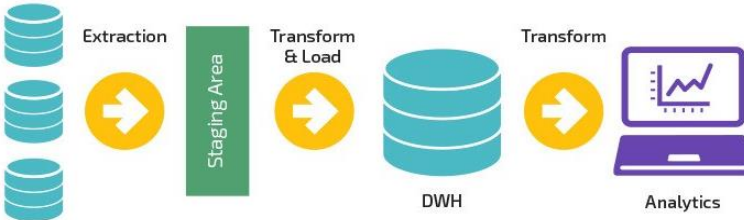

Gambar 4. Proses ETL

\subsubsection{Proses Extraction}

Pada tahap pertama akan dilakukan proses Extraction atau pengambilan data yang sesuai dengan yang dibutuhkan pada penelitian ini. Proses ekstraksi berjalan melalui basis data dengan sebelumnya dilakukan filtering dengan berbagai kriteria yang dibutuhkan dalam memilih dan menemukan data yang kemudian mentransportasikan data tersebut.

Ekstraksi data diambil dari sumber data SIMRS, akan dilakukan pada data registrasi kunjungan pasien pada bulan Juni 2018 hingga bulan Mei 2020 . Kemudian data tersebut akan dimasukkan kedalam tabel data staging sebelum masuk ke dalam data warehouse.

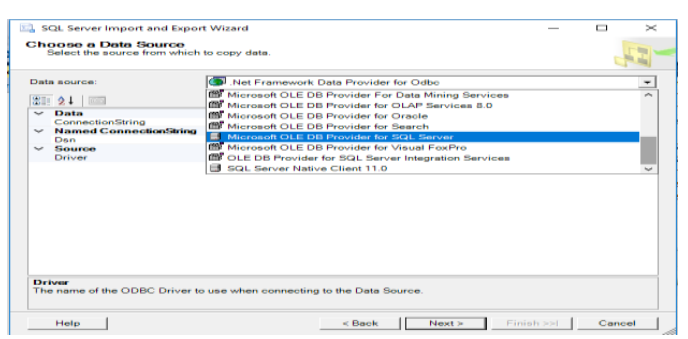

Gambar 5. Memilih data source

\subsubsection{Proses Transformation}

Setelah data warehouse mendapatkan data yang telah di ekstrak dari database SIMRS, dimana data yang diolah adalah data registrasi kunjungan pasien selama 2 tahun beroperasional rumah sakit dalam rangka menjadikannya sebuah informasi bermakna. Format data yang telah dikelompokkan, sistem akan melakukan transformasi sederhana yang termasuk didalamnya proses cleaning serta integrasi. Beberapa hal yang dilakukan pada proses transformasi adalah memilih atribut yang digunakan, menabahkan atribut data yang diperlukan, menghapus atribut yang tidak diperlukan serta deleting record yang bernilai 'null' atau tidak memiliki nilai kemudian menggabungkan berbagai kolom menjadi sebuah kolom dengan memberikan nilai. Data yang telah terseleksi setelah itu dilakukan proses cleansing, hasil dari proses pembersian data dan proses transformasi akan dimasukkan ke data staging atau temporary database.

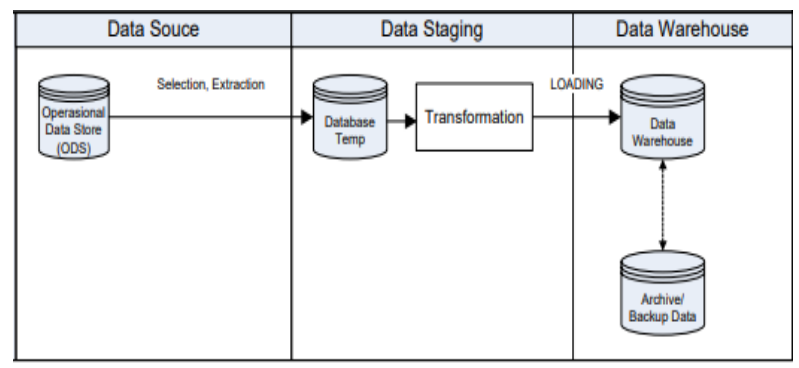

Gambar 6. Proses transformation

\subsubsection{Proses Loading}

Pada tahap terakhir ini, proses loading berfungsi untuk memasukkan data ke dalam data warehouse yang menjadi target akhir dalam proses ETL. Data yang telah masuk pada tahap ini dapat dipastikan telah melalui proses penyeragaman menjadi format tertentu, dimana hasil dari transformasi data akan dimasukkan ke data warehouse, selanjutnya akan dilanjutkan pada proses pengolahan data user interface berbentuk chart dan grafik, barulah para pengguna bisa mengakses hasil dari tahapan akhir ini dalam bentuk data maupun informasi. Dalam penyajiannya dilakukan dalam bentuk format laporan tertentu maupun dalam bentuk sekumpulan data yang dapat digunakan dalam analisis hingga dapat membantu dalam pengambilan keputusan. Dalam penelitian ini proses loading dilakukan menggunakan aplikasi Tableau Desktop dalam prosesnya dapat di lihat pada gambar 7 . 


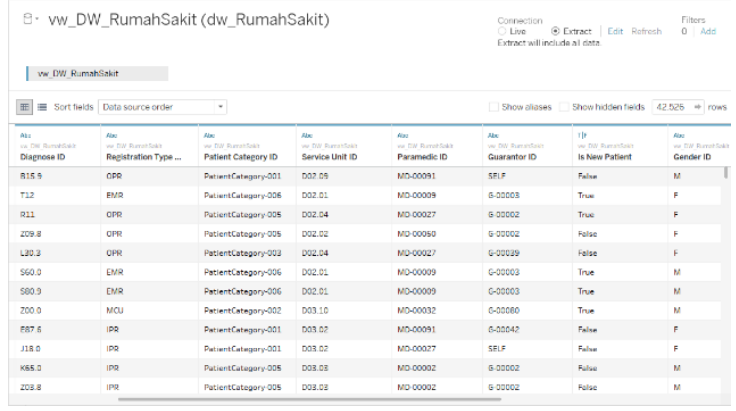

Gambar 7. Hasil loading source view dw_RumahSakit

Terdapat 42.526 rows yang dihasilkan dari proses loading pada View dw_RumahSakit, data ini yang akan digunakan dalam pengolahan OLAP menjadi report yang dibutuhkan guna membantu dalam menganalisa layanan kesehatan pada rumah sakit.

\subsubsection{Penerapan OLAP (Online Analytical Processing)}

Pada penelitian ini proses OLAP dilakukan dengan membuat data source view yang diberi nama dw_RumahSakit yang nantinya sebagai sumber data. Setelah rancangan data warehouse selesai dilakukan hingga terbentuknya dw_RumahSakit, maka tahapan berikutnya melakukan ekplorasi hasil laporan dan analisis data warehouse menggunakan software Tableau Desktop versi 2018.3 dengan teknik teknologi OLAP. Penerapan OLAP dilakukan guna memudahkan menampilkan data warehouse ke dalam format data multidimensional lalu dengan menggunakan feature antar muka aplikasi Tableau Desktop sehingga dapat dengan mudah diakses oleh pengguna.

Berikut ini merupakan gambaran dari proses Connection aplikasi Tableau Desktop ke database view dw_RumahSakit yang dibangun menggunakan Microsoft SQL Server, dapat dilihat pada gambar 8.
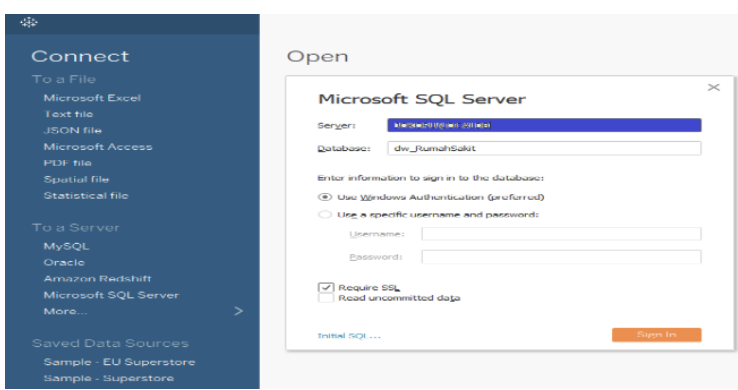

Gambar 8 Connection tableau desktop

Setelah itu dilakukan proses relasi terhadap dimensidimensi yang dibutuhkan pada eksplorasi hasil laporan dan analisis data warehouse. Dimana terdapat 11 dimensi yang akan direlasikan dengan source database view dw_RumahSakit. Proses tersebut dapat dilihat pada gambar 9 dibawah ini.

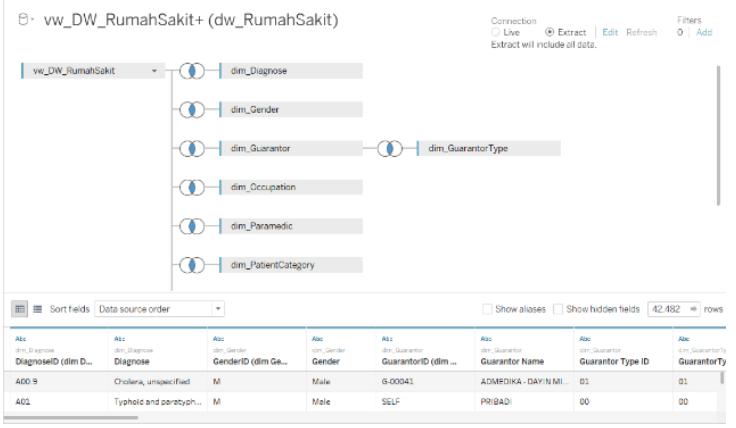

Gambar 9 Relation dimensions $d w_{-}$RumahSakit

\subsubsection{Eksplorasi Hasil Laporan dan Analisis Data Warehouse}

Pada bagian ini, penulis akan menampilkan informasi apa saja yang bisa diambil dari data warehouse rumah sakit. Dimana informasi yang akan dihasilkan berisikan data-data registrasi kunjungan pasien, pertumbuhan jumlah pasien serta diagnosa penyakit yang diderita pasien dengan di analisis berdasarkan 11 dimensi yang telah di Perekstrak dalam 2 tahun beroperasionalnya rumah sakit.

Adapun eksplorasi hasil laporan dan analisis data warehouse penulis melakukan simulasi dengan menjalankan hasil perancangan dengan menampilkan beberapa informasi berdasarkan skema yang telah dirancang. Berikut adalah tampilan informasi yang dapat di eksplorasi hasil laporan dan analisis data warehouse rumah sakit, namun tidak semua dapat ditampilkan.

a. Registrasi Kunjungan Pasien Berdasarkan Dimensi Tipe Registrasi Analisa Pertahun.

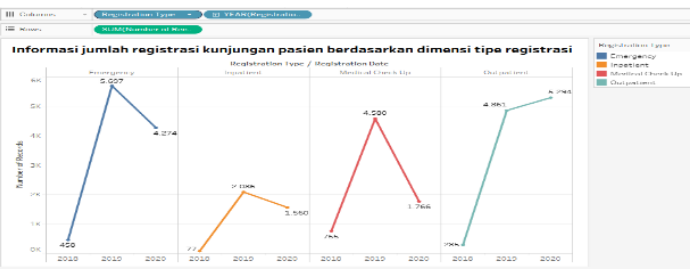

Gambar 10 Tampilan informasi jumlah registrasi kunjungan pasien pertahun

Berdasarkan dimensi tipe registrasi analisa pertahunnya, terlihat adanya pertumbuhan yang sangat signifikan pada setiap tahunnya. Hal ini menunjukkan pertumbuhan yang positif bagi rumah sakit diawal operasionalnya pada 2 tahun pertama beroperasionalnya

b. Registrasi Kunjungan Pasien Berdasarkan Dimensi Tipe Registrasi Analisa Perkuartal

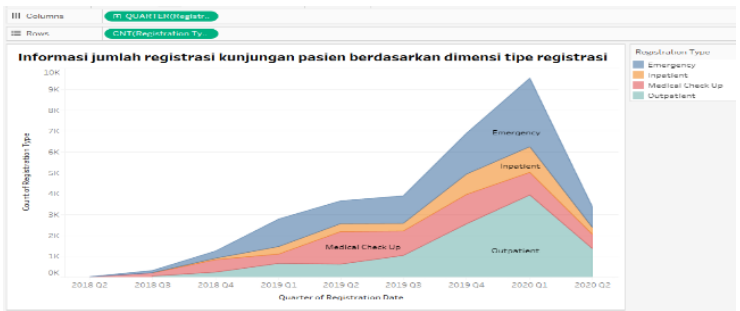




\section{Gambar 11 Tampilan informasi jumlah registrasi kunjungan pasien perkuartal}

Pada gambar 11 menunjukkan jumlah registrasi kunjungan pasien analisa perkuartal Q1 hingga Q4 pada setiap tahunnya mengalami pertumbuhan yang positif, agar tampilan lebih informatif dan menarik bagi pengambil keputuan dimana tampilan informasi dibuat lebih detail perkuartal dan dibuat chart berbeda namun yang lebih menarik lagi.

c. Registrasi Kunjungan Pasien Berdasarkan Dimensi Tipe Registrasi Analisa Perpekan

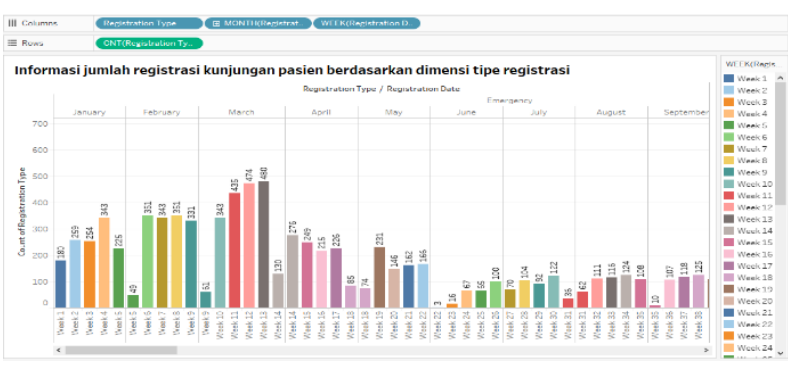

Gambar 12 Tampilan informasi jumlah registrasi kunjungan pasien perpekan

Pada gambar 12 terlihat lebih didetailkan hingga perminggu pada setiap tahunnya. Analisa semacam ini sangatlah dibutuhkan guna membantu manajemen mengevaluasi hasil dari layanan yang diberikan rumah sakit kepada seluruh pasiennya setiap minggunya.

d. Registrasi Kunjungan Pasien Berdasarkan Dimensi Tipe Registrasi Analisa Perhari

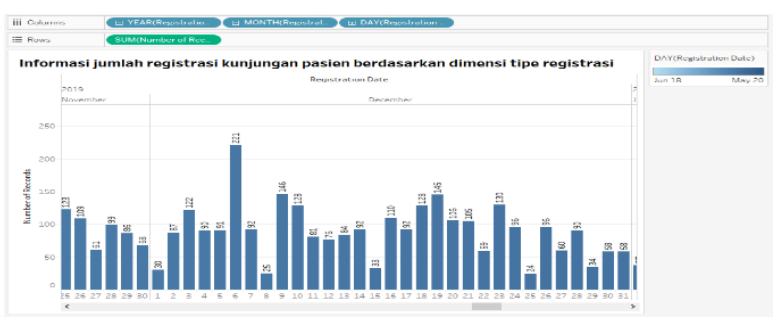

Gambar 13 Tampilan informasi jumlah registrasi kunjungan pasien perhari

Selain analisa pertahun, pekuartal hingga perminggu, laporan yang dihasilkan dari data warehouse, dapat pula dilakukan analisa hingga perhari (day to day). Report ini dilaporkan setiap harinya pada saat morning report.

e. Registrasi Kunjungan Pasien Berdasarkan Dimensi Service Unit Analisa Jumlah Kunjungan

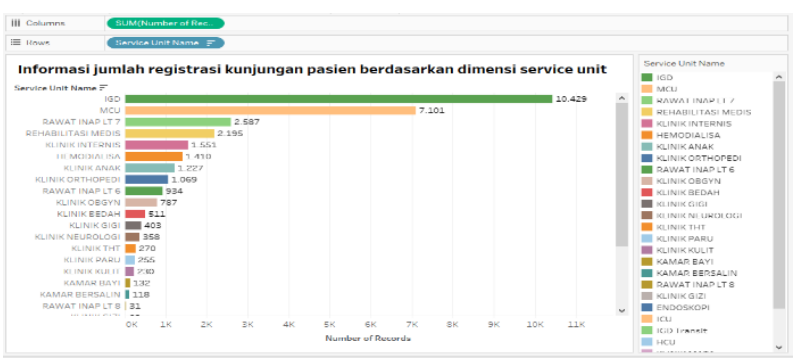

Gambar 14 Tampilan informasi jumlah registrasi kunjungan pasien perservice unit

Pada tampilan ini terlihat service unit IGD memiliki jumlah registrasi kunjungan paling banyak setelah itu diikuti service unit MCU. Hal ini wajar mengingat lokasi rumah sakit berada ditengah salah satu kawasan industri modern dan berada tepat pada jalur tol Jakarta Cikampek, sehingga banyak menangani kejadian kecelakaan kerja maupun kecelakaan lalu lintas.

f. Registrasi Kunjungan Pasien Berdasarkan Dimensi Service Unit Analisa Pertahun

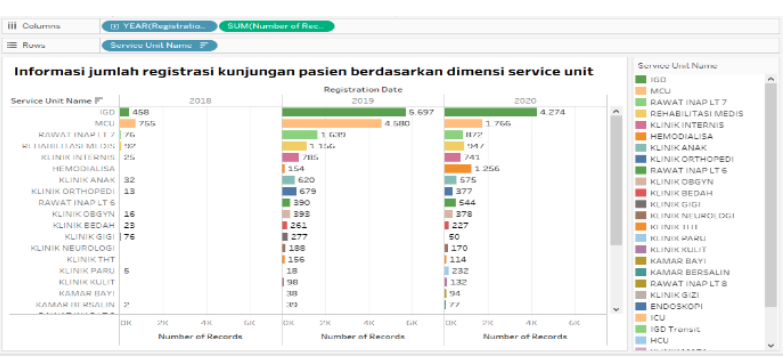

Gambar 15 Tampilan informasi jumlah registrasi kunjungan pasien perservice unit pertahun

Terlihat tipe penjamin perusahaan paling banyak menggunakan layanan kesehatan Medical Check Up. Hal ini dapat dikatakan sejalan dengan keberadaan rumah sakit dimana berlokasi disalah satu dikawasan industri modern, yang memiliki layanan utama Trauma Center dan Medical Check Up.

g. Registrasi Kunjungan Pasien Berdasarkan Dimensi Service Unit Analisa Perkategori Pasien

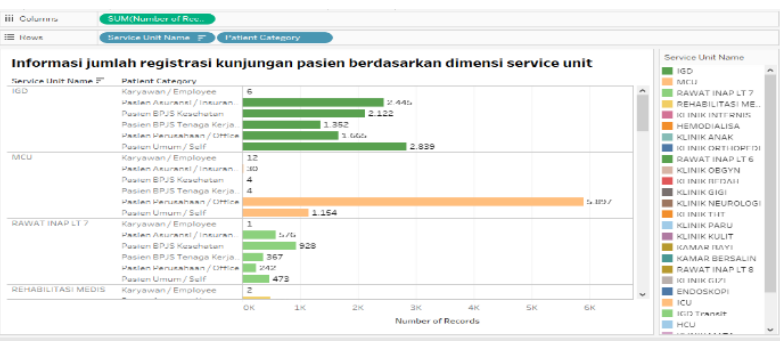

Gambar 16 Tampilan informasi jumlah registrasi kunjungan pasien perservice unit perpenjaminan

Terlihat kategori pasien perusahaan mendominasi jumlah registrasi kunjungan. Informasi ini memberikan gambaran buat bagian pemasaran rumah sakit dalam menentukan segement pemasarannya.

h. Registrasi Kunjungan Pasien Berdasarkan Dimensi Tipe Penjamin Analisa Pertahun

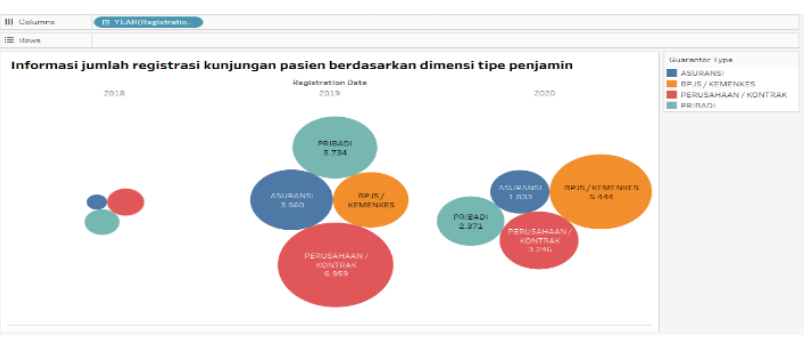


Gambar 17 Tampilan informasi jumlah registrasi kunjungan pasien pertipe penjaminan pertahun

Terlihat market share tipe penjamin pasien terbesar ada 4 tipe penjamin terbesar yang menggunakan layanan kesehatan rumah sakit. Dengan adanya laporan ini dapat digunakan manajemen dalam menjaga mutu layanan kesehatan yang diberikan, salah satunya dengan memberikan layanan medis secara Electronic Medical Record (EMR), ataupun memberikan layanan lingkungan rumah sakit yang modern salah satunya dengan layanan digital registrasi kunjungan pasien.

i. Registrasi Kunjungan Pasien Berdasarkan Dimensi Pertumbuhan Pasien Analisa Perkuartal

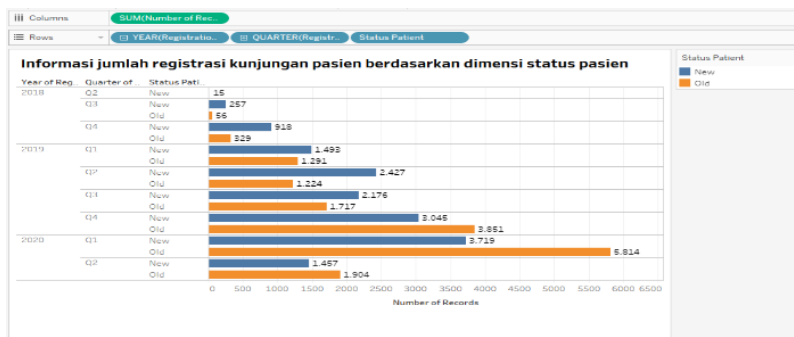

Gambar 18 Tampilan informasi pertumbuhan jumlah pasien perkuartal

Pada gambar 18 setiap tahunnya pertumbuhan jumlah pasien baru menunjukkan peningkatan pada setiap kuartalnya sekalipun ada penurunan pada quartal ketiga tahun lalu.

j. Registrasi Kunjungan Pasien Berdasarkan Dimensi Pertumbuhan Pasien Analisa Pertipe registrasi

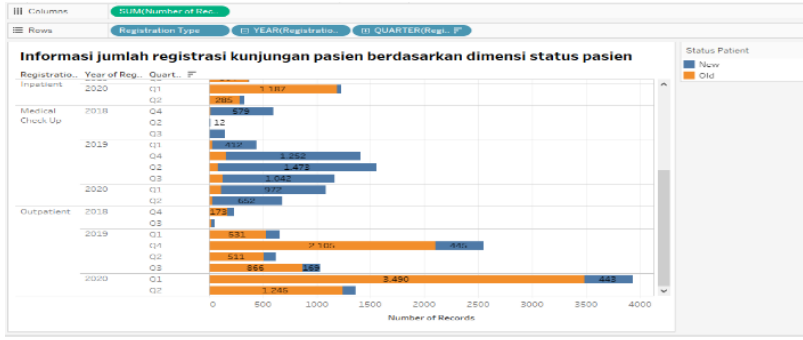

Gambar 19 Tampilan informasi pertumbuhan jumlah pasien analisa pertipe registrasi

Terlihat pertumbuhan pasien baru terbanyak pada tipe registrasi Medical Check Up pada tahun 2019 mendominasi pertumbuhan pasien baru.

k. Registrasi Kunjungan Pasien Berdasarkan Dimensi Diagnosa Pasien

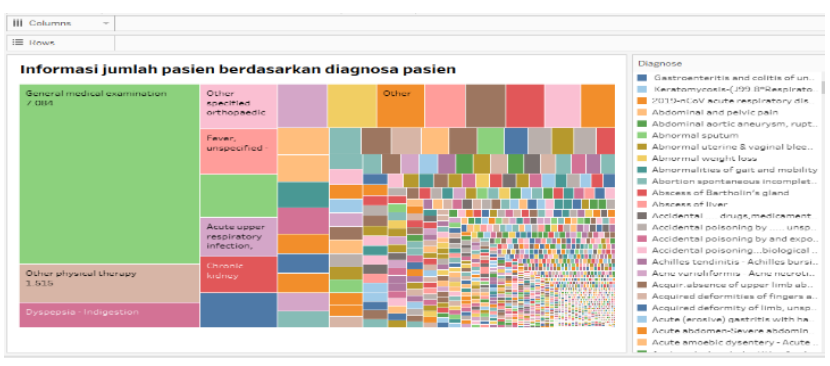

Gambar 20 Tampilan informasi pasien berdasarkan diagnosa pasien
Pada laporan ini ditampilkan diagnosa dari seluruh unit pelayanan. Didapati dominasi diagnonas general medical examination yang berasal dari unit layanan Medical Check Up tercatat paling banyak pada setiap tahunnya. Sedangkan untuk other physical therapy mendominasi kedua, diagnosa ini berasal dari unit layanan Rehab Medis.

1. Registrasi Kunjungan Pasien Berdasarkan Dimensi Jenis Kelamin Pasien Pertipe Registrasi

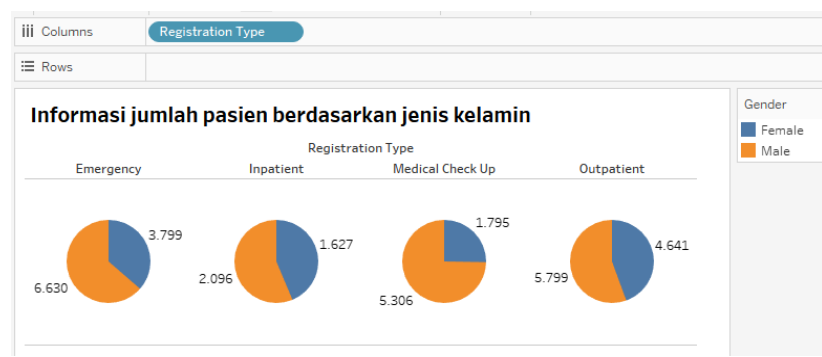

Gambar 21 Tampilan informasi pasien berdasarkan jenis kelamin analisa pertipe registrasi

Pada gambar 21 menjelaskan informasi jumlah registrasi kunjungan pasien berdasarkan dimensi jenis kelamin dimana jenis kelamin Laki-Laki mendominasi dibandingkan wanita pada setiap tipe registrasi baik Emergency, Medical Check Up, Outpatient maupun Inpatient.

\subsubsection{Evaluasi data warehouse}

Evaluasi dari ekplorasi hasil laporan dilakukan dengan menyebarkan kuesioner kepada para pengguna yang terdiri dari: Direktur, Manajer Marketing, Manajer Yankes, Manajer Keperawatan dan Manajer Keuangan. Dimana kuesioner memiliki 5 indikator penilaian untuk mengetahui penilaian penggunaan terhadap laporan yang dihasilkan data warehouse. Skala penilaian terdiri dari 4 jenjang yaitu kurang baik dengan skor 1, cukup baik dengan skor 2, baik dengan skor 3 dan sangat baik dengan skor 4 .

\begin{tabular}{|l|r|r|r|r|c|c|}
\hline \multirow{2}{*}{ Indikator } & \multicolumn{3}{c|}{ Responden } & \multirow{2}{*}{ Jumlah } \\
\cline { 2 - 6 } & 1 & 2 & 3 & 4 & 5 & \\
\hline Kemudahan Pengoperasian aplikasi & 3 & 3 & 3 & 2 & 3 & 14 \\
\hline Kemampuan aplikasi dalam menghasilkan laporan & 3 & 4 & 2 & 3 & 3 & 15 \\
\hline Keakuratan informasi yang dihasilkan & 2 & 3 & 3 & 4 & 2 & 14 \\
\hline Tampilan laporan yang dihasilkan & 4 & 3 & 2 & 3 & 2 & 14 \\
\hline Kemudahan dalam memahami laporan & 3 & 2 & 3 & 4 & 3 & 15 \\
\hline \multicolumn{1}{|c|}{ Jumlah } & 16 & 17 & 16 & 20 & 18 & 72 \\
\hline
\end{tabular}

Hasil dari penilaian yang didapat dari kuesioner dilakukan rumus persamaan 1:

$$
\frac{\text { Skor aktual }}{\text { Skor ideal }} \times 100 \%
$$

Skor aktual : jumlah skor hasil kuesioner

Keterangan:

Skor ideal : (skor tertinggi butir indicator) * butir indikator) * (jumlah responden)

Didapati nilai skor aktual 85, sedangkan untuk nilai skor ideal adalah $4 * 5 * 5=100$, maka dapat ditarik penilaian terhadap hasil perancangan data warehouse adalah $72 / 100=0.72$ maka jika dipersentasikan $72 \%$. 
Setelah itu dilakukan perhitungan nilai interval untuk setiap kategorinya bernilai $100 \%: 4=25 \%$, maka dapat ditentukan kategori penilaian menjadi:

Kategori 1: 0 - 24,99\% untuk kategori kurang baik, baik,

Kategori 2: $25 \%$ - 49,99\% untuk kategori cukup

Kategori 3: 50\% - 74,99\% untuk kategori baik dan

Kategori 4: $75 \%$ - 100\% untuk kategori sangat baik. Dari hasil kuesioner didapati penialaian pengguna sebesar $72 \%$ terhadap hasil perancangan data warehouse sehingga masuk dalam kategori baik.

\section{KESIMPULAN \& SARAN}

\subsection{KESIMPULAN}

Dari hasil perancangan data warehouse rumah sakit, penulis dapat menarik beberapa kesimpulan sebagai berikut:

1. Penggunaan data warehouse rumah sakit dinilai bermanfaat dalam mengelola data dengan jumlah data yang cukup besar, sehingga diharapkan kebutuhan informasi pelayanan kesehatan rumah sakit dapat terpenuhi.

2. Data warehouse rumah sakit berdaya guna untuk menganalisa data registrasi kunjungan pasien sehingga didapati informasi jumlah registrasi kunjungan dari berbagai dimensi, pengunaannya dapat digunakan untuk analisa pertambahan pasien dari tiap dimensi yang akan bermanfaat dalam pengambilan keputusan manajemen guna meningkatkan mutu pelayanan kesehatan rumah sakit dapat diwujudkan.

3. Selain itu data warehouse juga dapat memberikan informasi data diagonsa pasien secara detail dari berbagai dimensi yang dapat dianalisa sehingga diharapkan rumah sakit dapat menganalisa kebutuhan yang dibutuhkan guna meningkatkan mutu pelayanan rumah sakit.

\subsection{SARAN}

Peneliti memaparkan beberapa saran untuk penelitian selanjutnya sebagi berikut:

1. Peneliti memberikan saran ruang lingkup data pada data warehouse dapat lebih diperluas lagi hingga mencakup pelayanan kesehatan penunjang medis hingga pelayanan tindakan operasi. Serta dengan jumlah data yang lebih besar lagi seiring berkembangnya rumah sakit, guna meningkatkan mutu pelayanan kesehatan rumah sakit.

2. Peneliti menyarankan kedepannya dilakukan pengembangan lebih lanjut hingga ketahap penerapan data mining agar hasil dari analisi data diharapkan dapat lebih mendalam dan lebih terpola lagi dengan pendekatan yang ada pada sistem data mining. Sehingga data-data dalam jumlah besar lebih terorganisir, terkelompokkan dan lebih mudah diproses guna meningkatkan mutu pelayanan kesehatan rumah sakit.

3. Peneliti juga memberi saran untuk pengembangan tampilan antarmuka yang lebih menarik serta lebih dinamis lagi kedepannya. Dan diharapkan dapat digunakan secara lebih luas lagi guna meningkatkan mutu pelayanan kesehatan rumah sakit.

\section{DAFTAR PUSTAKA}

ABAI, NUR HANI ZULKIFLI, JAMAIAH H. YAHAYA, \& AZIZ DERAMAN. 2013. "User Requirement Analysis in Data warehouseDesign: A Review." Procedia Technology11 (Iceei). Elsevier B.V.: 801-6. https://doi.org/10.1016/j.protcy.2013.12.261.

AHMAD, I. 2000. Data Warehousing in Construction Organizations. Construction Congress VI : Building Together for a Better Tomorrow in an Increasingly Complex World. Orlando: American Society of Civil Engineers.

BALLARD, CHUCK, FARREL, M. DANIEL. 2006, Dimensional Modelling : In a Business Intelligence Environment, IBM RedBooks, USA

CHANDRA, A. 2010. Perancangan Data Warehouse pada Software Laboratory Center (Jurnal). Jakarta : Fakultas Ilmu Komputer Universitas Bina Nusantara.

CONNOLLY, T. \& CAROLYN B. 2005. Database Systems : A Practical Approach to Design, Implementation, and Management. Addison Wesley.

GOLFARELLI, M., HILL, M.G., \& RIZZI, S. Data Warehouse Design, Modern Principles and Methodologies. Mc Graw Hill.

INMON, W.H. 2005. Building the Data warehouse, Fourth Edition. Wiley Publishing.

KIMBALL, R.; \& CASERTA, J. 2004. The Data Warehouse ETL Toolkit : Practical Techniques for Extracting,Cleaning, Conforming, and Delivering Data. Indianapolis. Wiley.

KIMBALL, R. \& MARGY R. 2013. The Data Warehouse Toolkit : The Definitive Guide to Dimensional Modeling, Third Edition. John Wiley \& Sons.

MADYATMADJA, E.D, M. AWAN W, SUCIPTO A, \& GUSTI A.D.V. 2012. Manfaat Data Warehouse pada Rumah Sakit ABC (Jurnal). Jakarta : School of Information System Universitas Bina Nusantara.

MAKIANI. 2013. RSUD Palembang Bari. (Online). Tersedia:http://rsudpbari.palembang.go.id/ark/id/7 6 (28 Mei 2020)

NUR ARDISTA. 2016. Design and Implementation of Data Warehouse for Reporting and Analysis Data of Outpatient Visits at Airlangga University Hospital based on Online Analytical Processing (OLAP).

PONNIAH, P. 2001. Data Warehousing Fundamentals : A Comprehensive Guide for IT Profesionals. John Wiley \& Sons.

REDDY, G. S., SRINIVASU, R., RAO, M. P., \& RIKKULA, S.R. 2010. Data Warehousing, Data Mining, OLAP and OLTP Technologies are Essential Elements to Support Decision-Making 
Process in Industries. International Journal on Computer Science and Engineering , 2 (9), 28652873.

SHETA, O.E. DAN AHMED N.E. 2013. The Technology of Using A Data Warehouse to Support Decision-Making in Health Care. International Journal of Database Management Systems Volume 5 Nomor 3 Tahun 2013.

SUZANA, M. 2013. Analisis dan Perancangan Data Warehouse Rumah Sakit Umum Daerah Palembang Bari. Palembang : Fakultas Ilmu Komputer Universitas Bina Darma.

TURBAN, E., RAINER, R. K., \& POTTER, R. E. 2005. Introduction to Information Technology. Canada: John Wiley \& Sons.

WILLIAM, C. AMO. Microsoft SQL ServerOLAP Developer's Guide. Foster City,CA : IDG Books Worldwide, 2000.

VASSILIADIS, P., SIMITSIS, A., \& SKIADOPOULUS, S. 2002. Conceptual Modeling for ETL Processes. 
Halaman ini sengaja dikosongkan 